III-2 | 2011

Pragmatism and the Social Sciences. A Century of Influences and Interactions, vol. 1

\title{
Neo-Pragmatim and Phenomenology
}

\section{A Proposal}

Patrick Baert

\section{(2) OpenEdition}

\section{Journals}

Electronic version

URL: http://journals.openedition.org/ejpap/816

DOI: 10.4000/ejpap.816

ISSN: 2036-4091

\section{Publisher}

Associazione Pragma

\section{Electronic reference}

Patrick Baert, "Neo-Pragmatim and Phenomenology », European Journal of Pragmatism and American Philosophy [Online], III-2 | 2011, Online since 29 December 2011, connection on 01 May 2019. URL: http://journals.openedition.org/ejpap/816 ; DOI : 10.4000/ejpap.816

This text was automatically generated on 1 May 2019.

\section{c) (†) $९$}

Author retains copyright and grants the European Journal of Pragmatism and American Philosophy right of first publication with the work simultaneously licensed under a Creative Commons AttributionNonCommercial-NoDerivatives 4.0 International License. 


\title{
Neo-Pragmatim and Phenomenology
}

\author{
A Proposal
}

Patrick Baert

\section{Introduction}

1 In this chapter, I will elaborate on the precise nature of the neo-pragmatist agenda for the social sciences which I have been developing over the last couple of years and which I have tried to crystallize in Philosophy of the Sciences: Towards Pragmatism (Baert 2005) and a number of other publications (e.g. Baert 2006, 2007). I will argue that this neo-pragmatist agenda changes our priorities about social research. Its significance can be shown especially in relation to the writings of a number of authors, who engage with Husserl's phenomenology. There is much to be gained by integrating insights from American neopragmatism and, in particular Emmanuel Levinas, Hans-Georg Gadamer and Jean-Paul Sartre. Although prima facie very different, these three Continental-European authors have a non-representational view of knowledge and language in common, as well as a commitment to putting the ongoing engagement with difference at the centre of philosophy. I will argue that this new way of thinking about philosophy has repercussions for how we conduct social research in ways that tie in especially neatly with the recent debates around, for instance, public sociology.

2 By pragmatism I refer to the distinct philosophical tradition, initially set in motion by Charles Peirce, later developed by William James and John Dewey, and further articulated by Richard Bernstein and Richard Rorty. This philosophical tradition is often portrayed as quintessentially American, and for very good reasons. Not only did the major pragmatists live and work in the US. Their philosophical works emerged in response to distinctly American problems and concerns; they expressed distinctly American sentiments, hopes and anxieties. This is not to say that pragmatism is solely an American enterprise. Some European philosophers of the nineteenth century, like Henri Bergson and Friedrich Nietzsche, developed views which were remarkably close to those of pragmatism, as did 
the Oxford-based philosopher F.C. S. Schiller at the beginning of the twentieth century. Some of the older generation of American pragmatists studied in Europe, had regular intellectual exchanges with European intellectuals and were very much indebted to them. More recent exponents of pragmatist philosophy, like Rorty and Bernstein, engaged with and saw affinities with a number of Continental European authors who were considered seriously out of line within the analytical tradition. The multiplicity of influences is not surprising, given that American pragmatism has always portrayed itself as nondoctrinaire, open and receptive to new ideas, in contrast with the boundaryconsciousness of analytical philosophy and its general disdain towards much written in the German and French tradition.

3 If American pragmatism has been shown to be open to European philosophy, the latter has been less receptive towards the former. There are notable exceptions like Jürgen Habermas (1981a, 1981b, 1994 [1968]), whose critique of positivism and theory of communicative action drew on Peirce and the pragmatist tradition. All too often, however, Pragmatism has been discarded as a parochial endeavour, too deeply ingrained in American society and its problems to appeal to a broader philosophical audience. Underlying my contribution is the conviction that this picture of pragmatism is deeply misleading. By integrating American neo-pragmatism and phenomenology, I will demonstrate not only the bearing of pragmatism on contemporary philosophy of social science, but also the fruitfulness of a continued dialogue between the two traditions which on the surface look so different.

4 Although the argument which I will develop here is inspired by pragmatist philosophy, noably by Bernstein and Rorty's neo-pragmatism, this is not to say that either of them would endorse the views that I develop, let alone express them precisely in the way in which I do. Although generally sympathetic to their outlook, the problems addressed in this chapter and the questions asked are quite different from those of the neopragmatists, and the argument elaborated stands very much on its own.

5 This article consists of six parts. The first section discusses which components of pragmatist philosophy are central to my proposal for the philosophy of social science, and the second section demonstrates how my perspective differs from the two approaches that dominate the philosophy of social science and social research. The third section explores the relationship between my agenda and Sartre's ontology, in particular his distinction between Being-in-itself and Being-for-itself. The fourth section explains how my approach draws on Levinas' conceptualisation of otherness, and the fifth shows how my pragmatist-inspired proposal ties in with Gadamer's dialogical notion of understanding. Finally, the article shows the contemporary relevance of my proposal by focusing on the significance of social research for society.

\section{Pragmatism and Pragmatisms}

Before we proceed further, it is important to gain clarity as to the meaning of "pragmatism" and a "pragmatist agenda" as opposed to the employment of the term in everyday language. People often equate "pragmatism" with a "pragmatic" attitude, according to which action ought not to be guided by a priori principles but primarily by an assessment of the actual constraints and opportunities of a given context. In foreign policy, the label "pragmatism" refers precisely to this non-ideological stance, whereby political actors routinely seek to gauge and take advantage of what comes their way. 
Likewise, when social scientists label research as "pragmatist," sometimes they mean that it does not follow rigid methodological principles and instead exhibits an eclectic or opportunistic choice and application of method. In those circumstances, I prefer to term this a "pragmatic" attitude to distinguish it from the "pragmatist" argument developed here. So a pragmatic stance implies that the choice of theories or techniques depends on the particular topic of investigation or situation at hand rather than on a well-articulated philosophical or theoretical position.

7 My argument for a pragmatist stance has little in common with the methodological opportunism that characterises a pragmatic attitude. Firstly, I am not arguing that social researchers should pick and choose the theoretical framework or technique that somehow "fits" or "corresponds" best to the data or that seems opportune given the circumstances. I am actually sceptical of this view, not in the least because it draws on a problematic metaphor of vision as if social research is meant to mirror the external social world as accurately as possible (of which more in section two). Secondly, whilst a pragmatic attitude questions the usefulness of any philosophical account for social research, pragmatism questions the value of some philosophical debates, in particular about essences or ontology, and it also doubts the merit of some philosophical views, for instance, foundationalism. Pragmatism is sceptical of intellectual disputes if taking one or another position has no practical consequences for anyone (James 1907). For pragmatists, questions about inner essences or ontology are such scholastic enterprises because answering them in one way or another makes no practical difference.

What is the common ground which pragmatist philosophers share? What distinguishes the pragmatist outlook from those of other philosophical traditions? And which of the pragmatists' ideas have influenced my own agenda for the philosophy of the social sciences? To identify which ideas are shared by pragmatists is not a sinecure because pragmatism was, and still is, a heterogeneous entity. From the beginning, pragmatism entailed competing branches and antithetical positions, even to the extent that Charles Peirce, who coined the term, later distanced himself from "pragmatism" because he felt that some of the beliefs carried under this banner were so alien to his. It is ironic that some philosophers, whom we now regard as iconic figures of the pragmatist movement, occasionally invoked other labels to refer to themselves, with Peirce's "pragmaticism" and Dewey's "instrumentalism" being particularly poignant examples. More recently, Richard Bernstein, Donald Davidson, Nelson Goodman, Hilary Putnam and Richard Rorty have taken pragmatism into uncharted territories (such as literary criticism and critical theory). This has led commentators to question whether some of those contemporary developments can be as easily reconciled with earlier forms of pragmatism as the likes of Rorty would have us believe.

Nevertheless, it would be a mistake to infer from this that pragmatists have little in common. Most pragmatist philosophers - old and new - share a number of key ideas, which makes it possible to talk about a pragmatist movement. It is particularly important to illustrate a number of these ideas here because they underscore my perspective on the philosophy of the social sciences.

10 To start with, few commentators mention the humanist tendencies of pragmatism, which is surprising given how pervasive humanism is amongst classical and contemporary pragmatists and how essential it is to their intellectual project. William James (1911: 121-35), John Dewey (1994) and F. C. S. Schiller $(1903,1907)$ occasionally used the term to contextualise their own work, though they attributed different meanings to it. By 
humanism I refer to a particular perspective according to which cognitive, ethical and aesthetic claims, including claims about those claims, are intertwined with human projects and are predominantly human creations. Not only ought those claims to be judged on their practical contribution to society, they are also social and cultural in nature, often entailing the cooperation of many individuals and drawing on a complex web of symbols and cultural codes. The social and cultural dimension of those claims has, in turn, a number of repercussions, of which the rejection of both foundationalism and objective knowledge are particularly important.

11 By foundationalism one refers to the belief that philosophy can establish a-temporal, universal foundations that secure aesthetic, ethical or cognitive claims. Historically, a significant number of philosophers conceived of their work as primarily a foundational enterprise. To be foundational in this sense, philosophy ought to be able to step outside history - outside culture or language - so as to adopt a "neutral" position from which the right kind of prescriptions can be made. Most pragmatists take an anti-foundationalist stance. They believe that philosophical reflection cannot achieve this position of neutrality because it is, like other intellectual accomplishments, a human activity; and as a human activity, a social activity; and as a social activity, a situated activity (see, for instance, Peirce 1877, 1878; Dewey 1938; Rorty 1982: xiiff.; Bernstein 1991: 326ff.). This means that philosophical knowledge, like any other kind of knowledge, is always partial: it takes place from a certain vantage point. Pragmatists call for humility amongst philosophers, because, no matter what the amount of cleaning work they do, philosophy can never remove those human stains. As such, it cannot obtain the neutral stance which foundationalism requires.

12 A similar argument applies to other forms of knowledge, including scientific knowledge (Dewey 1929; James 1907). Scientific knowledge, too, is situated, partial, enacted from a particular viewpoint. Logical positivists spent a great deal of effort showing that scientific knowledge is superior to other forms of knowledge because it supposedly meets stringent criteria of objectivity. In this context, one talks about objective knowledge if it is not affected significantly by the attitudes and values of those who obtain this knowledge. In contrast, pragmatists insist that scientific knowledge is an intervention in the world and that, as an intervention, it is necessarily shaped by the interests or focus of the researchers involved. This does not mean that knowledge is necessarily always subjective, if by subjective we mean that it fails to represent the external world accurately. In fact, pragmatists avoid using the label "subjective" altogether; firstly, because it implies the possibility of objective knowledge in the way in which logical positivism postulated it; and secondly, because it mistakenly assumes that knowledge has something to do with the copying of the external world.

Descartes' method supposedly provided philosophical foundations that ensure infallible knowledge. In contrast, the pragmatist world is indicative of what Hilary Putnam called the "democratisation of inquiry": devoid of foundations, people are encouraged to reassess their views in the light of new empirical evidence (Putnam 2004). Various pragmatists might interpret this fallibilism differently. For the older generation of pragmatists, like Peirce, Dewey and Mead, scientific conjectures are empirically tested and, if necessary, replaced by superior scientific conjectures. It is the confrontation with new empirical phenomena that precipitates doubt, which only subsides once the old theory has been adjusted. Neo-pragmatists are less concerned with scientific discovery and change. They are more interested in how communities can adopt new vocabularies, 
redescribing themselves in the light of the new information provided. Rich, vital cultures are confident enough to exhibit openness towards uncomfortable experiences. As such, they are well-equipped to redescribe and reinvent themselves. However, in both cases, anti-foundationalism goes hand in hand with a genuine fallibilist attitude whereby people are willing to question entrenched beliefs and replace them with more useful ones.

I already hinted earlier at the pragmatist rejection of the mirror view of knowledge (see, for instance, James 1907; Dewey 1929; Rorty 1980, 1999: 47-71). This mirror view conceives of knowledge in terms of passive and accurate recording of the essence of the external world. In this view, the external world is taken to be independent of human experience, waiting to be discovered. This pictorial view has its intellectual origins in the Platonic perspective on knowledge. Plato took knowledge as passive contemplation as opposed to active involvement; only the philosophers' contemplation would allow proper and unmediated access to the real world. The mirror view is widespread both in philosophical and scientific circles, and it assumes an opposition between theory and knowledge on the one hand, and practice and action on the other. Knowledge is taken to be passive and instantaneous, whereas action is, by definition, active and proceeds through time. One of the up-shots of this view is that knowledge should no longer be judged on the basis of its isomorphic relationship to the external realm, but on the basis of what kind of contribution it makes to our world. For too long, the dualism between theory and practice and its attendant preoccupation with accurate representation has led western philosophers to ignore the practical difference knowledge can make. Pragmatism breaks with this dualism and takes seriously the notion of scientific engagement.

\section{Pragmatist-Inspired Philosophy of Social Science}

Pragmatism, as outlined above, has significant repercussions for the philosophy of the social sciences. The philosophy of social science is a meta-theoretical enterprise which reflects on the nature and workings of social research, often leading to recommendations about which methodology or theory should be used. My pragmatist-inspired perspective on the philosophy of social science draws on the insights illustrated in the previous section and on the integration of pragmatism and continental philosophy (infra). This perspective, centred around the notion of self-understanding, is diametrically opposed to two perspectives which have dominated the mainstream of the philosophy of social science, and which I call "representationalism" and "methodological naturalism." In what follows I describe and criticise these two perspectives, and this will allow me to discuss in more detail the contours of my perspective.

To start with, "representationalism" is a widespread position in meta-theoretical reflections on the social sciences, though more implicit than overtly defended or propagated. Representationalists presuppose that social research aims to map or depict the social world as accurately and completely as possible, with social theory providing the necessary building blocks for this social cartography. Empirical research is regarded as fruitful if the theory used is shown to be eminently applicable and to allow for the social cartography to take place effectively. Amongst those who adhere to this philosophical outlook are structuralists, structuration theorists and critical realists, although most do so implicitly rather than defending it explicitly. The problems with representationalism are twofold, one referring to the mechanical and repetitive nature of the research conducted under its banner, and the other referring to its flawed notion of knowledge. 
Firstly, it makes for repetitive and uninspiring research, whereby a particular theoretical framework, to which a group of researchers is committed, is habitually applied to new settings, and thereby continually used and reproduced. In this social cartography model, empirical research reinforces the theory that is used, rather than checking its validity. As empirical research is no longer seen as a testing device but as providing instantiations of a given theory (and so yielding yet further evidence that the theory "fits" various situations), the possibility of theoretical innovation is very limited and operates only within the contours set by the theory. Secondly, representationalists assume what John Dewey facetiously called the "spectator theory of knowledge" according to which knowledge mysteriously captures the inner essence of the external world (Dewey 1929). As seen in the previous section, the spectator theory of knowledge is problematic, relying as it does on a passive notion of knowledge acquisition as if it is a flaccid mirroring of the outer world (Rorty 1980; 1999: xvi-xxxii, 23-46). Also, it fails to grasp the temporal dimension of knowledge acquisition, the extent to which it is the outcome of a process rather than an instantaneous occurrence. In this context, it is worth invoking Dewey's distinction between "knowledge" and "experience": whereas the latter alludes to a passive and immediate sensation of the outer world, the former refers to the outcome of an active process of reflection (Dewey 1910, 1929). The spectator theory of knowledge erroneously conflates the immediacy and passivity that is characteristic of experience with that of knowledge, thereby promoting a flawed notion of "immediate knowledge." More generally, influenced by Darwinism, the early generation of pragmatists already conceived of knowledge in terms of process and action, insisting that knowledge is one of the tools people use to adjust, cope and interact with their external surroundings (Mead 1936, 1938). While from an evolutionary point of view, the intricate link between knowledge, process and action is imminently plausible, it is more difficult to see how, through time, people would have managed to develop knowledge that represents the world as it really is. Similar to Gadamer for whom any act of description or making sense of the external world draws on a variety of presuppositions which give the representation direction and shape, pragmatists are committed to a holistic perspective according to which so-called statements of fact always tie in with theoretical presuppositions.

Moving to the second meta-theoretical perspective, a significant number of philosophers of social science are committed "methodological naturalists," searching for a unifying scientific method which would be applicable to both the natural and social sciences. Within the discipline of philosophy falsificationists and critical realists subscribe to methodological naturalism, whereas in the social sciences diverse research programmes, ranging from rational choice theory to Durkheim-inspired structural analysis, accept this philosophical position albeit often implicitly rather than discursively formulated. Methodological naturalism should not be confused with "ontological naturalism," which assumes that the social and the natural sciences are comprised of the same substance. Methodological naturalism assumes that a distinctive method underlies most, if not all, successful scientific activities, and that philosophical reflection can show why this method is so superior to others. This means that methodological naturalists hold two distinct, though related views, one being philosophical and the other historical. On the one hand, they are wedded to a foundationalist outlook which supposedly captures the essence of science - that which distinguishes it from lesser forms of knowledge acquisition like religion, ideology or pseudo-science. On the other hand, they hold a particular historical view according to which the natural sciences have employed this successful methodological strategy for quite a while whereas the social sciences, being 
too close to their subject matter, have consistently failed to do so. Unsurprisingly, naturalist philosophers of social sciences often make recommendations for social research, urging it to grow up and emulate the "mature science" which can be found in the departments of physics and chemistry.

As indicated in the earlier section, pragmatists tend to question the virtues of foundationalist reasoning in general, and in this case the empirical studies of science seem to confirm this scepticism. Contrary to the naturalist agenda, studies in the history and in sociology of science show that the closer we look at the actual workings of scientists, the less support emerges for a unifying methodology within the natural sciences, let alone across the natural and social sciences (e.g. Latour \& Woolgar 1979). There is a growing awareness that scientific research does not fit neat, objectivist criteria, that various disciplines operate quite differently, and that within each discipline there are national and local traditions which culminate in distinct methodological practices to such an extent that it is no longer warranted to talk about a unifying method.

Whereas naturalist philosophies of social science take for granted that social research is primarily an explanatory (and possibly predictive) endeavour, a pragmatist-inspired perspective explores the intricate relationship between method and cognitive interests and refuses to take for granted that explanation and prediction are the only legitimate cognitive interests (see also Rorty 1982: 191-210). Besides explanation and prediction, pragmatists also consider other cognitive interests to be integral to the social sciences, amongst which are meaningful understanding, social critique and emancipation, and (importantly for my argument) self-understanding (Baert 2005: 146-69). Whereas classical pragmatists focused on the problem solving qualities of science, my neo-pragmatist perspective, influenced by Rorty's appropriation of the German notion of Bildung or selfedification, underscores the importance of the notion of self-understanding. This concept refers to the process by which knowledge can help groups of people redescribe, reevaluate and reconceptualise themselves. Major breakthroughs in science have often been accompanied by substantial changes in the way in which people conceptualised themselves. In some cases, such as with Darwinism, this even led to a radical rethinking of the position of humanity as a whole.

Self-understanding occupies a particularly central place in the humanities and the social sciences, serving as they do to encourage groups of people to rethink who they are in the face of a confrontation with other forms of meaningful activity. This explains why some commentators go as far as arguing that the emergence of sociology or the social sciences is itself a sign of increasing collective self-knowledge under conditions of modernity (Wagner 1994). Crucially, when academics in the humanities and social sciences are asked to list the intellectual milestones of their discipline, they tend to select works which bring about this Gestalt-switch. Whereas self-understanding might be an interesting corollary of significant transformations in the natural sciences, the case of the humanities and social sciences is quite different as self-understanding is absolutely integral to what makes for a substantial work in this area of the academy. Key contributions to social research might obtain other cognitive interests - for instance, they might exhibit strong explanatory or predictive power -, but ultimately, I argue, self-understanding remains the key criterion by which the significance of a piece of research will be judged (Baert 2007). Selfunderstanding does not imply that people necessarily agree on how to re-conceptualise themselves in the light of a new or established framework, and indeed there is often substantial disagreement on this score. But whether or not there is agreement, a 
significant contribution in the humanities and the social sciences forces individuals to reconsider some of their presuppositions about themselves in the face of the new narrative presented.

In what follows, I will discuss particular aspects of the work of Jean-Paul Sartre, Emmanuel Levinas and Hans-Georg Gadamer. By doing so, I will demonstrate that a dialogue between neo-pragmatism and European phenomenology is possible. More importantly, this fruitful dialogue leads to an identification of the key features of a method (and an ethos) of social research which revolves around the idea of selfunderstanding and which bears more promise for the social sciences than the current fixation on representationalism and methodological naturalism.

While Sartre, Levinas and Gadamer all engage with Husserl's phenomenology, each takes it in a direction different from Husserl's that is convergent with mine. What follows is not an attempt to rediscover or resuscitate Husserl's philosophy (which in crucial respects is diametrically opposed to my neo-pragmatist argument), but to show how subsequent developments within phenomenology help enrich a neo-pragmatist perspective on the philosophy of the social sciences. There is, however, one important link between my argument and Husserl's which is worth mentioning at this stage. For Husserl, philosophy is not merely an intellectual enterprise without external value; it is also a means for obtaining self-knowledge or self-discovery. Philosophy enables the individual to create a useful distance towards him- or herself and to conceptualise the self differently. This, so Husserl argued, would eventually help to create a form of freedom. The neo-pragmatist argument, which I have been developing, takes equally seriously this notion of selfknowledge and recognises the important role philosophy may play in achieving it. There are differences, though, between the neo-pragmatist use of self-knowledge and that of Husserl. Essential to my argument is that the social sciences - not philosophy - are particularly well-placed for achieving it. Also different from Husserl's individualist reading is the neo-pragmatist argument that self-knowledge is a collective achievement; it is something shared by members of a community.

\section{Sartre and Epistemological Authenticity}

23 My neo-pragmatist philosophy of the social sciences shows striking affinities with the existentialist phenomenology as it was developed by Martin Heidegger and Jean-Paul Sartre. Both Heidegger and Sartre engage critically with Husserl's writings and take phenomenology in a new direction, which I would argue is closer to pragmatist philosophy. Firstly, like pragmatists, existentialist phenomenologists recognise the quintessentially human nature of cognitive, ethical and aesthetic claims. This position leads, amongst other things, to the questioning of both the possibility of objectivity and of the viability of epistemology, because it is no longer held possible for philosophers and scientists to decipher a neutral algorithm that would allow them to escape history and culture. Secondly, like pragmatists, existential phenomenologists reject the opposition or dualism between the subject and an independent external world. As people's knowledge is seen as inevitably embedded in and practically engaged with the world, the opposition between the knower and known, assumed by both realism and idealism, becomes a mere artificial intellectual construct. Thirdly, both philosophical strands - pragmatism and existential phenomenology - reject the spectator theory of knowledge according to which knowledge mirrors or captures the external world. Indeed existentialist 
phenomenologists distanced themselves from Husserl whose notion of the transcendental ego - a disembodied, detached ego - was indicative of the way in which he was still wedded to a spectator theory of knowledge. In contrast with the spectator theory that conceives of objects as vorhanden ("present-at-hand," detached), existentialists emphasise that people encounter objects first and foremost as zuhanden ("ready-to-hand," like a tool). Pragmatists and existentialists argue that the form of reflexive intelligence, which is characteristic of vorhanden, only arises when people are confronted with unexpected experiences. Fourthly, whereas Husserl's phenomenology conceives of meaning in terms of essences and senses of words, existentialist phenomenology resembles pragmatism in promoting a holistic picture and in demonstrating the intricate link between understanding and purposive action. So in contrast with Husserl, pragmatists and existentialists subscribe to Wittgenstein's later views about meaning and how it is embedded in larger systems or "forms of life."

In clarifying the connections between the neo-pragmatist agenda and existentialist phenomenology, Sartre's L'être et le néant (1943) and L'existentialisme est un humanisme (1996) are particularly instructive. Sartre's anti-essentialism manifests itself in his refusal to accept that human beings - any human being, as a matter of fact - can be defined in terms of a set of fixed characteristics. However subtle a description of an individual, he or she is always able to overcome this account and prove otherwise through his or her actions. Ultimately, people are nothing but the sum of their actions, so it is a fallacy, for instance, to say that a person who acted cowardly all his life was deep down truly courageous (Sartre 1996: 26-7, 29-30). People might adopt strategies to deny their intrinsic freedom, and there are indeed various instances of this bad faith, but a genuinely full life requires that one acknowledges the freedom which one has and makes choices whilst ensuring that others are free as well. Freedom is also at the heart of Sartre's distinction between being-in-itself and being-for-itself. Whereas being-in-itself exists independent of consciousness and can therefore only be what it is, being-for-itself refers to the fluid aspect of human existence. It was Hegel who initially coined the term "being-for-itself" to refer to the uniquely self-conscious dimension of human being, the extent to which individuals are, unlike objects, able to reflect on the conditions of their existence and to act accordingly. Likewise, Sartre's notion of being-for-itself centres round the reflexive component of human existence, capturing as it does the ability of human beings to transcend the most structurally constraining of circumstances and ultimately their capacity to exercise genuine freedom even in the face of severe adversity (Sartre 1943: 109-41).

Sartre focused on individuals and individual decisions but his arguments can be translated into a social vocabulary, a move which helps to further clarify the neopragmatist proposal which I have been advocating. Just as Sartre argued that individuals have the freedom to define themselves and to deny the categories that are imposed on them, a given social setting does not necessitate a specific account, descriptions or explanation. Just like individuals who, by virtue of their self-consciousness, escape fixed descriptions, any social setting can be redescribed and rearticulated ad infinitum and there is no a priori reason to rule out any of those accounts on epistemological grounds. Both representationalists and naturalists are mistaken in searching for a final vocabulary that would mysteriously "fit" a given social situation because the epistemological or theoretical justifications provided have been shown to be flawed. For social researchers to search for such a final vocabulary is basically to act in what Sartre would call bad faith 
(Sartre 1943: 81-106): that is, for them to deny their own undeniable freedom to present new, exciting narratives, to string together the kind of storylines which makes us look at old themes in novel, interesting ways (see also Rorty 1980: 365-79). There are various academic, institutional forces that entice social researchers to deny their own freedom, be it the urge for "scientific" recognition or the loyalties to established academic clans and their patriarchs. Firstly, whether positivist or falsificationist, researchers often allude to "science" or "scientific procedures" to justify the methodological decisions they make. However, as I have pointed out in the above and elsewhere, references to "the scientific method" are always problematic given the methodological diversity between scientific disciplines and even within them. Secondly, institutionalised loyalties towards an intellectual school (or towards a mentor) risk culminating in repetitive practice whereby empirical research is seen simply as an instantiation of the theoretical framework or general orientation that is being adopted. It is difficult to break those loyalties given the power relations involved and the extent to which they are tied in with academic job prospects and career progression.

In a nutshell, my argument for a neo-pragmatist perspective, with its acknowledgement that there is no neutral algorithm that will help us decide which theories or methods to adopt, calls on researchers to escape those epistemological and institutional constraints and to acknowledge the freedom to construct innovative narratives and help communities redefine themselves. Following on from Sartre's notion of "authenticity" (as the mirror image of bad faith) (Sartre: 70-1), what I am proposing could be described as "epistemological authenticity," by which I mean that researchers ought to cast off epistemological shackles, recognising their intellectual ability to shatter established storylines and their moral responsibility to do so.

\section{Levinas and the Encounter with the Other}

My argument for a pragmatist-inspired philosophy centred around the idea of selfunderstanding ties in with Emmanuel Levinas' arguments put forward in his Théorie de l'intuition dans la phénoménologie de Husserl (1970 [1930]), Le temps et l'autre (1991 [1947]), Autrement qu'être ou au-delà de l'essence (1974) and in particular in his magnum opus Totalité et infini (1961). Compared to other French philosophers referred to as operating neatly within the phenomenological tradition, like Maurice Merleau-Ponty, Paul Ricoeur or Jean-Luc Marion, Levinas occupies such a distinctive position and his central claims are so strongly opposed to Husserl's philosophy that it is difficult to justify labelling his work as unambiguously phenomenological. Influenced by Franz Rosenzweig and Martin Buber, Levinas' divergence from Husserl and other phenomenologists stems from their failure to recognise the distinctiveness and irreducibility of the Other, and Levinas tries to show the implications of that failure for philosophy. From his early writings onwards, Levinas shows interest in the notion of escape, which refers to the positive need of the individual to avoid the facticity of existence and in particular to break with the sheer individual experience of being oneself. From the point of view of the later Levinas, the individual can only achieve this distantiation towards the self by engaging properly with alterity. In this regard, Levinas' position heralds those of Edward Said and Homi Bhabha developed half a century later. They denounce a large proportion of western thought and literary criticism for not engaging sufficiently with different cultures and for imposing their own dichotomies on what is by all accounts a radically different cultural landscape. 

an ethical shift in existential phenomenology, exploring as he does the extent to which the confrontation with others imposes a variety of obligations on the individual. However, for my purposes, Levinas' attention to the relationship between alterity and dialogue is more important. While Levinas wants to hold onto Husserl's position that intentionality represents the world through the mediation of consciousness, he is very keen to emphasise that the encounter with the external world makes for a dynamic exchange whereby the subject engages with and is affected by the Other. Comparably to Gadamer's dialogical notion of understanding, Levinas sees the confrontation with alterity also as an opportunity for the self to reassert, re-evaluate and redefine itself. In the face of otherness, the self can undergo change while still retaining its sameness (Levinas 1961: 5-10).

31 Despite his notoriously nebulous language and his lack of interest in the status and objectives of contemporary social research, Levinas' treatment of the complex relationship between self and alterity is relevant here because of its substantial bearing for a pragmatist-inspired philosophy of social science. Few social researchers and indeed even fewer philosophers of social science show a genuine interest in the concept of otherness, let alone incorporate it into their writings. In their particular endeavours to obtain reliable knowledge of the social world, neither the representationalist nor the naturalist perspective on the social sciences engages properly with otherness. Wedded to a spectator theory of knowledge, the social cartography model treats the encounter with otherness in a way that reinforces the theoretical framework in operation, thereby replicating familiar theories and undoing the unfamiliarity of empirical experiences. Likewise, naturalists tend to use metaphors and analogies with well-known phenomena 
to explain and possibly predict new, unfamiliar phenomena, thereby again failing to engage properly with, and learn from, what is being studied. In both cases, the methodology is used as a strategic weapon to negate a genuine encounter with different forms of life - to ensure, in other words, that no real surprises are in store. The pragmatist-inspired philosophical project, on the other hand, conceives of the encountering of different forms of life as an enormous opportunity to redescribe, reassess, and recreate ourselves (Rorty 1999: 87-8). In Levinasian parlance, one of the central tenets of my proposal is to conceive of social research as a proper engagement with otherness, refusing to reduce alterity to sameness. The key to this research programme is a dialogical model, which cuts right across the traditional dichotomy between the knower and the known. For this, it proves particular useful to draw on Gadamer's account of understanding, which is more developed than Levinas'.

\section{Gadamer and the Pursuit of Self-Understanding}

Whereas Levinas' thought is embedded in the phenomenological tradition, Gadamer's central arguments, as developed in Wahrheit und Methode (1975), are often seen as entrenched in hermeneutics. It is indeed true that Gadamer situates himself very much in relation to the "romantic hermeneutics" of Wilhelm Dilthey and other nineteenth century authors. However, Husserl and Heidegger's influences loom large, especially where Gadamer decides to deviate from nineteenth century hermeneutic authors. Gadamer shares Dilthey's critique of positivist attempts to model the Geisteswissenschaften onto the natural sciences, but disagrees with Dilthey's project to put the social and historical sciences on as secure, objective a footing as the natural sciences (Gadamer 1975: 162-250). Central to Gadamer's position is Husserl and Heidegger's argument that the objective natural sciences can only emerge within a historically engraved "life-world." Parallel to my own rejection of naturalism, Gadamer argues that the standards of "objectivity," which are associated with the natural sciences, ought not to be seen as norms for knowledge tout court because those "scientific" yardsticks, like any criteria, have developed within a particular tradition. Similarly to the pragmatist call for methodological diversity, Gadamer insists that to treat "scientific" criteria of "objectivity" as the standards of knowledge is to neglect other historically situated norms and criteria. In opposition to the Cartesian preoccupation with a method of objective understanding, Gadamer's "philosophical hermeneutics" explores the conditions of possibility of understanding. This philosophical project puts him on a collision course with the Enlightenment orthodoxy which conceives of tradition and prejudice (Vorurteil) as impediments to proper understanding. For Gadamer, nothing could be further from the truth because understanding cannot take place without tradition and prejudice. Resembling the pragmatist critique of the Enlightenment search for a neutral algorithm for knowledge (Rorty 1999: xii-xxxii), Gadamer argues that any appeal to reason and method also necessarily draws on tradition and prejudice and thereby inevitably invokes what was meant to be eradicated. However, if Gadamer claims that tradition and prejudice are a sine qua non for understanding, he does not mean that understanding is an individual or arbitrary accomplishment. Mirroring the pragmatist insistence on the social and historical nature of knowledge claims, Gadamer treats tradition as a shared experience, rooted in and developed within a long historical trajectory. Gadamer coins 
the term "effective history" (Wirkungs geschichte) to refer to the way in which tradition and its history affects us even when we try to shed their power (Gadamer 1975: 250-360).

It would be easy to misinterpret Gadamer or to infer the wrong conclusions from his work. From Gadamer's assertion that understanding is always socially and historically constituted, we should not infer that researchers, like other individuals, have a philosophical licence simply to impose their categories and presuppositions on what they study. We have seen earlier how the social cartography model adopts this erroneous view of research, projecting as it does theoretical categories onto the empirical material, and thereby replicating and reinforcing them. As I have indicated in the above, the upshot of this representational perspective is a peculiar form of theoretical ossification whereby empirical material is devalued and treated as simply an instantiation of the theoretical framework to which the research is wedded. In contrast, Gadamer's notion of genuine understanding is quite different because it ties in with what I called self-understanding; that is with the recognition of one's own fallibility and a willingness to learn and see things differently. Just like an authentic dialogue whereby participants are treated on an equal footing and are prepared to find out about other points of view, genuine understanding or Verständigung involves openness towards the unfamiliar and a willingness to learn from it in the hope of reaching an agreement. In a move which is particularly relevant to my argument about the significance of self-knowledge in social research, Gadamer contends that, in the case of genuine understanding, people are willing to recognise the validity and coherence of what is being studied to such an extent that this recognition might undermine some of their own presuppositions. In Gadamer's terminology, understanding eventually leads to "self-formation" or Bildung, the process by which individuals and communities take on a larger perspective and realise the fallibility or parochial nature of beliefs they have hitherto cherished. Eventually, selfformation does not simply imply that people obtain knowledge of new forms of life but also that they acquire deftness in obtaining that type of knowledge. The gebildete culture is one in which people have acquired the ability to judge and discern (Gadamer 1975: 7-16, 77ff.).

Following on from Levinas' mission to preserve the distinctiveness of the Other against on-going attempts to assimilate it to the familiar, Gadamer's dialogical perspective on understanding and his notion of Bildung tie in neatly with the concept of selfunderstanding that occupies such a central role in my pragmatist-inspired perspective. However, whereas Gadamer considers the relationship between understanding and selfunderstanding in ontological terms, my pragmatist-inspired perspective wants to exploit it methodologically. The question, then, is no longer whether understanding necessarily entails an element of self-understanding, but how to use this notion of self-understanding as a criterion to evaluate and judge social research, and, conversely, which methodological strategies can be conceived to bring about this reflexive stance. As shown elsewhere, genealogical historians, post-processual archaeologists and the exponents of the critical turn in anthropology have been effective in pursuing self-understanding in this sense (Baert 2005: 157-65), though it is worth emphasising they have done so within the specific intellectual climate in which they were writing, and that there is no guarantee that their methodological orientations will remain equally successful in the future or in a different context. So to appeal for a methodological reading of the dialogical notion of understanding is not to invoke yet another elusive neutral algorithm, but it is to be sensitive to the cultural importance of self-knowledge and the central role 
the social sciences can play in this, and to reflect on the methodological strategies which in a given context are well suited for this purpose. The picture that emerges is one in which social research is seen as an encounter with otherness, potentially facilitating or encouraging a community to reflect on its presuppositions, including those that underlie the research. In contrast with traditional philosophy of social science that has little regard for self-edification, my appeal for a gebildete research revolves around the importance of the broadening of people's perspectives.

\section{Social Research, Reflexivity and Societal Engagement}

In contrast to their contemporaries in Vienna and Cambridge, classical pragmatists, like Dewey and Mead, wanted philosophy and the social sciences to engage with the social world, to make it a richer, more diverse and altogether more interesting place. Dewey's contributions to educational theory are a case in point, and so is the sociological research conducted by members of the Chicago School (see, for instance, Abbot 1999, Joas 1993). These examples show philosophy and the social sciences at their best, interacting with and learning from the external world, and attempting to give something back to the communities that are being studied. Since then the further institutionalisation of academics within university establishments and the intense professionalisation of the social sciences has led to quite a different set-up (see, for instance, Jacoby 1986). This shift has certainly not been altogether negative, bringing legitimacy and outside recognition, securing improved work conditions and setting rigorous standards of intellectual quality. However, in relation to the initial pragmatist ambitions about the relationship between knowledge and practice, those institutional transformations have meant that intellectual legitimacy and academic recognition have become stronger priorities than practical engagement. Whereas earlier sociologists addressed significant political and social concerns, the upshot of the structural changes is that social scientists increasingly address other social scientists and that their language and intellectual interests reflect and reinforce this narrowing of horizons.

Against this backdrop, my argument for a new way of thinking about social research, centred around an integration of American neo-pragmatism and Continental philosophy, acquires an element of urgency. In contrast with the academic setting today, social research in pursuit of self-understanding encourages researchers to be sufficiently open to the unfamiliar, to take a broader perspective and reflect on the world we took for granted hitherto. This type of research is about expanding our imaginative canvas and practical reach, something to be achieved by learning from and reaching out to those beyond the safe contours of the academy.

My argument in particular shows affinities with Michael Burawoy's recent plea for a "public sociology," which uses expert knowledge to promote debate with and amongst various non-academic publics, thereby responding and adjusting to their demands and ultimately providing "dialogue" and "mutual education" (Burawoy 2004, 2005). Burawoy compares his notion of "organic" public sociology with "traditional" public sociology: whereas the latter addresses an amorphous, invisible and mainstream public, the former actively engages with a specific, visible and politically organised group of people. Both forms of public sociology can perfectly coexist and indeed feed into each other, but Burawoy argues particularly in favour of the organic version because its political mandate is better articulated, it has clearer direction and its practical pay-off is less 
ambiguous. Public sociology, so he argues, is not only different from mainstream "professional sociology" but also from "policy sociology." While policy sociology attempts to provide technical answers to questions provided by an external client, public sociology develops a "dialogic relationship" between sociology and the public whereby the issues of each partner are brought to the attention of the other, and each adjusts or responds accordingly. Whereas both professional and policy sociology construct "instrumental knowledge," public sociology shares with "critical sociology" a preoccupation with "reflexive knowledge" or "dialogue about ends." Public sociology should not be conflated with critical sociology, however: whereas both professional and critical sociology target an academic audience, public sociology, like policy sociology, embarks on a dialogue with non-academic publics about the "normative foundations" of society.

While Burawoy's passionate argument for a more socially engaged sociology is appealing and indeed has obtained worldwide attention, he focuses mainly on the actual practical engagement of sociologists with their publics. Less attention is given to exploring the type of knowledge acquisition involved in the kind of reflexive sociology which he promotes. Following the distinction by the Frankfurt School between substantive and instrumental rationality, Burawoy differentiates reflexive sociology from policy sociology on the basis that it establishes goals and values rather than means. But this definition remains notoriously vague, especially given that what counts as a value in one context can be a means for acquiring a value in a different context. Meta-theoretical discussions about the future of the discipline of sociology, as the debate around public sociology certainly is, need to be accompanied by philosophical explorations of the methodological issues involved. Otherwise the arguments presented have a hollow ring to them and can easily be dismissed as mere statements of intent, devoid of any substance.

The pragmatist-inspired proposal, outlined here - with its rejection of foundationalism, naturalism and representationalism, its emphasis on self-understanding, and its exploration of the link between knowledge and action - provides the right philosophical backing to support and define the type of social scientific knowledge that engages with groups and communities outside the safe contours of the ivory tower. However, this is not to say that the Gadamerian dialogical model of knowledge, for which I have been arguing, is solely relevant for non-academic publics. Social research in the pursuit of selfunderstanding cuts right across Burawoy's distinction between critical and public sociology because the reflexivity that is built in affects presuppositions that are held within academic as well as non-academic communities.

This is particularly clear in the case of Zygmunt Bauman's Modernity and the Holocaust (1991) - a prime example of the type of research I have in mind. This not only invites a broader non-academic audience to rethink the nature of the atrocities during the Third Reich, but also challenges some of the presuppositions sociologists and philosophers hold about the value, the possibilities and the dangers of the transition towards modernity. Challenging the Sonderweg thesis and opposing the orthodox view that modernity and the Holocaust are antithetical, Bauman persuasively argues that key features of modernity the "garden" notion of the nation-state, and a process of bureaucratisation with its increasing instrumental rationality and decreasing sense of individual responsibility were necessary conditions for the emergence of the Holocaust. By doing so, Bauman goes further than arguing against the popular conception that the atrocities committed during that period were somehow irrational outbursts or indicative of the fact that the project of modernity had not quite been accomplished. Crucially, his analysis also implies that 
sociologists ought to reassess their views about the project of modernity itself, a reassessment which ultimately affects how they conceive of their own discipline, entrenched as it is in the Enlightenment vision. In short, this example indicates that, in practice, the rigid distinction between Burawoy's critical and public sociology may be less relevant than he assumes it is. This is because any substantial dialogical knowledge, of the kind I have been arguing for and which Bauman epitomises, will be relevant to both academic and non-academic communities.

\section{Conclusion}

This chapter has sought to demonstrate the fruitfulness of an ongoing dialogue between American neo-pragmatism and Continental philosophy, which, for far too long, have been regarded as addressing irreconcilable intellectual concerns. It has explored the affinities which exist between my own neo-pragmatist agenda in the field of philosophy of the social sciences, and the philosophical outlook developed by Sartre, Levinas and Gadamer. Rather than conceiving of social research as, primarily, an explanatory or predictive endeavour, I have shown that this neo-pragmatist view promotes social research in terms of an ongoing engagement with otherness, a process which ultimately contributes to the pursuit of richer forms of collective redescription. In this view, research takes a central role in the ability of communities to distance themselves from their hitherto unacknowledged presuppositions, to assume different points of view and, ultimately, to make a difference to the social world which those communities have helped to create and which they inhabit. This neo-pragmatist approach, I have argued, presents a philosophical basis for the reflexive knowledge entailed in both critical and public sociology.

One final issue needs to be addressed. As my neo-pragmatist perspective aims to contribute to the philosophy of the social sciences, the question inevitably arises which theories are well (or ill-) suited to bringing about the reflexivity which I have been advocating? From the above, it should be clear that my answer is that, unlike other philosophies of social science such as falsificationism or critical realism, this pragmatistinspired proposal is neutral vis-à-vis theory choice in so far as it refuses to invoke external criteria - such as falsifiability, explanatory power or predictive success - to decide on the value of a given theory. Instead, it suggests that we should take into account the context of the dominant presuppositions of the discipline or indeed of a community at large before evaluating the theory under consideration because it is only against this background that such an evaluation can beachieved. Alfred Schutz's notion of "stock of knowledge at hand" is particularly applicable here because it captures very well how, in their everyday life, people approach the social world in terms of "familiarity and preacquaintanceship" (Schutz \& Luckmann 1973). Just as everyday life is embedded in the Lebenswelt - a world of everyday life governed by the "natural attitude" - social researchers take for granted a number of theoretical and metaphysical beliefs and methodological strategies. It follows from the above that theories ought to be evaluated on the basis of how much of a Gestalt-switch they manage to bring about - how much they could bring researchers to rethink those hitherto deeply entrenched and often unacknowledged presuppositions. In opposition to the ritualistic hero-worship, which is so endemic in the social sciences today and which is tied in with the representational model of social researcher, the pragmatist-inspired perspective calls for less deference 
and bolder claims - an intellectual iconoclasm of sorts. The question should no longer be how we can apply the works of our intellectual heroes or preferred models (whatever they are) to the empirical data, but how we can learn from the encounter with the unfamiliar to challenge them and think differently.

\section{BIBLIOGRAPHY}

Аввотт A., (1999), Department and Discipline: Chicago School at One Hundred, Chicago, University of Chicago Press.

BAERT P., (2005), Philosophy of the Social Sciences: Towards Pragmatism, Cambridge, Polity Press.

BAERT P., (2006), "Social Theory and the Social Sciences," in Delanty G., (ed.), Handbook of Contemporary European Social Theory, London, Routledge.

BAERT P., (2007), "Why Study the Social," in Baert P. \& Turner B. S., (eds.), Pragmatism and European Social Theory, Oxford, Bardwell Press.

BAUMAn Z., (1989), Modernity and the Holocaust, Cambridge, Polity Press.

BERNSTEIN R. J., (1991), The New Constellation. The Ethical-Political Horizons of Modernity/Postmodernity, Cambridge, Polity.

BuraWoy M., (2004), “Public Sociologies: A Symposium from Boston College," Social Problems 51, 103-30.

BURAWoy M., (2005), “2004 Presidential Address: For Public Sociology,” American Sociological Review 70, 4-28.

DEWEY J., (1910), The Influence of Darwin on Philosophy, New York, Henry Holt.

DEWEY J., (1929), The Quest for Certainty, New York, Henry Holt.

DEWEY J., (1938), Logic: The Theory of Inquiry, New York, Holt, Rinehart and Winston.

DEWEY J., (1994), Religious Faith and Democratic Humanism, New York, Columbia University Press.

GADAMER H. G., (1975 [1960]), Wahrheit und Methode: Grundzüge einer philosophischen Hermeneutik, Tübingen, Mohr.

HABERMAS J., (1994 [1968]), Erkenntnis und Interesse, Frankfurt am Main, Suhrkamp.

HABERMAS J., (1981a), Theorie des kommunikativen Handelns; Bd 1. Handlungsrationalität und gesellschaftliche Rationalisierung, Frankfurt am Main, Suhrkamp.

HABERMAS J., (1981b), Theorie des kommunikativen Handelns; Bd 2. Zur Kritik der funktionalistischen Vernunft, Frankfurt am Main, Suhrkamp.

JACOBY R., (1986), The Last Intellectuals: American Culture in the Age of the Academe, New York, Noonday Press.

JAMES W., (1907), Pragmatism, a New Name for Some Old Ways of Thinking. Popular Lectures on Philosophy, London, Longmans, Green \& Co. 
JAMES W., (1911), The Meaning of Truth, New York, Longman Green.

JOAS H., (1993), Pragmatism and Social Theory, Chicago, University of Chicago Press.

LATOUR B. \& S. WOOLGAR, (1979), Laboratory Life: The Social Construction of Scientific Facts, London, Sage.

LEVINAS E., (1967), En découvrant l'existence avec Husserl et Heidegger, Paris, Bril.

LEVINAS E., (1978 [1947]), De l'existence à l'existant, Paris, Vrin.

LEVINAS E., (1970 [1930]), Théorie de l'intuition dans la phénoménoloie de Husserl, Paris, Vrin.

LEVINAS E., (1991 [1947]), Le temps et l'autre, Paris, Presses Universitaires de France. LEVINAS E., (1961), Totalité et infini; Essai sur l'extériorité, Librairie général Française.

LEVINAS E., (1974), Autrement qu'être, ou, au-delà de l'essence, La Haye, Martinus Nijhoff.

PEIRCE C., (1877), “The Fixation of Beliefs," Popular Science Monthly 12, 1-15.

PEIRCE C., (1878), “How to Make our Ideas Clear," Popular Science Monthly 12, 286-302.

PUTNAM H., (2004), The Collapse of the Fact/Value Dichotomy and Other Essays, Cambridge, Mass., Harvard University Press.

RORTY R., (1980), Philosophy and the Mirror of Nature, Oxford, Blackwell.

RORTY R., (1982), Consequences of Pragmatism, Hempel Hempstead, Harvester Wheatsheaf.

RORTY R., (1999), Philosophy and Social Hope, Harmondsworth, Penguin.

SARTRE J.-P., (1943), L'être et le néant. Essai d'ontologie phénoménologique, Paris, Gallimard.

SARTRE J-P., (1996), L'existentialisme est un humanisme, Paris, Gallimard.

SCHILLER F. C. S., (1903), Humanism: Philosophical Essays, London, Macmillan.

SCHILLER F. C. S., (1907), Studies in Humanism, London, Macmillan.

SChutZ A. \& T. LUCKMANN, (1973), The Structures of the Life-World, Chicago (Ill.), North-western University Press.

WAGNER P., (1994), A Sociology of Modernity: Liberty and Discipline, London, Routledge.

\section{ABSTRACTS}

This article introduces a new pragmatist-inspired perspective on the social sciences. It explores the relevance of neo-pragmatism for the philosophy of the social sciences, showing how it can lead to innovative and groundbreaking social research. The paper attempts to drive home these insights by elaborating on the affinities of neo-pragmatism with some Continental philosophers who have engaged with Husserl's phenomenology, notably Gadamer, Levinas and Sartre. This neo-pragmatist proposal for the social sciences develops a non-representational view of knowledge and puts the ongoing engagement with difference at the centre of social research. From this perspective, the process of knowledge formation is dialogical in nature whereby the researcher learns as much from those who are being researched as vice versa. The concluding section aims to show the implications of this perspective for current research in the social sciences, throwing new light on contemporary meta-discussions about social research. 
Neo-Pragmatim and Phenomenology

19

AUTHOR

PATRICK BAERT

University of Cambridge pjnb100[at]cam.ac.uk

European Journal of Pragmatism and American Philosophy, III-2 | 2011 